Pak. j. sci. ind. res. Ser. B: Biol. sci. 2016 59(2) 69-74

\title{
Effect of Tillage Options and Straw Management on Crops Productivity and Soil Fertility in Rice-Wheat-Cropping Pattern
}

\author{
Md. Ilias Hossain ${ }^{\mathrm{a}}$, Md. Israil Hossain ${ }^{\mathrm{a}}$, Md. Nur-E-Alam Siddquie ${ }^{\mathrm{a}}$ and Md. Shahidul Haque ${ }^{\mathrm{b} *}$ \\ ${ }^{a}$ Regional Wheat Research Center, Shyampur, Rajshahi, Bangladesh \\ ${ }^{b}$ Department of Biochemistry and Molecular Biology, Laboratory of Protein and Enzyme Research, University \\ of Rajshahi, Rajshahi-6205, Bangladesh
}

(received January 23, 2015; revised January 1, 2016; accepted January 26, 2016)

\begin{abstract}
A field experiment was conducted during winter season to study the productivity under three $\mathrm{N}$ fertilizer levels $(80,100$ and $120 \% \mathrm{~N}$ of recommended dose), two levels of straw retention ( 0 and $30 \%)$ and three tillage options (permanent raised bed, fresh bed and conventional tillage practice) in a RiceWheat cropping system. Tillage options have been found to affect thousand grain weight (TGW) and grain yield where 49.6, 52.9 and $54.7 \mathrm{~g}$ for TGW and $3.77,3.98$ and $4.41 \mathrm{t} / \mathrm{ha}$ for grain yield for conventional, permanent bed and fresh bed, respectively were found for wheat. The spikes $/ \mathrm{m}^{2}$ was 343,322 and 337 while, the spikelets/spike were recorded as 17.2, 17.6 and 17.8 for conventional, permanent and fresh bed, respectively. Different tillage options were found to cause the formation of grains/spike, 43.2, 49.7 and 50.8 , respectively. Therefore, other yield components were assumed to be enhanced in response to fresh bed tillage option. Fresh bed with $30 \%$ straw retention produced highest productivity and similar results were also obtained from permanent beds with $30 \%$ straw retention. Fresh bed with $120 \%$ recommended $\mathrm{N}$ produced the highest productivity for wheat which was similar to permanent bed with $120 \% \mathrm{~N}$. The increase in yield was associated with progressive increase in all growth components and will give a new insight to identify the strategy for the development of wheat and other crops cultivation.
\end{abstract}

Keywords: tillage options, $\mathrm{N}$ fertilization, straw management, sequential cropping system, wheat yield

\section{Introduction}

Land degradation and soil fertility decline are among the main causes of the stagnation and fall of agricultural production in many tropical countries, including those with intensive irrigated cropping systems. Approximately $85 \%$ of the area planted with intensive rice-wheat (RW) sequential cropping is found in the Indo-Gangetic Plain (IGP) of South Asia in India, Pakistan, Nepal and Bangladesh (Timsina and Connor, 2001). Rice is transplanted in flat fields typically ponded for long periods or continuously from transplanting until shortly before harvest. This negatively affects soil properties for the following non-puddle crop (Sah et al., 2014). Wheat is then planted in these structurally disturbed soils, often after many tillage operations to prepare the seedbed or increasingly with little soil disturbance using zero-till seed drills. A change from growing crops on the flat to raised beds offers more effective control of irrigation water and drainage. This may be particularly beneficial for non-rice crops grown in rotation with rice, allowing better rainwater management during the monsoon season for rice. Connor et al. (2003) suggested that permanent raised beds might offer farmers further significant

*Author for correspondence; E-mail: haque_drshahidul@yahoo.co.in advantages such as increased opportunities for crop diversification, mechanical weeding and placement of fertilizers; relay cropping and inter-cropping; and reduced tillage and water saving. There are also indications that crop yields from beds can be further increased by using higher rates of $\mathrm{N}$ fertilizer and later irrigation because of the reduced risk of lodging (Wei et al., 2008). Raised beds are increasingly used in many developed and developing countries in mechanized agriculture but have been introduced only recently in Bangladesh, with the aim of improving system productivity (Talukder $e t$ al., 2002). The common practice of rice in puddle soils destroys the soil physical structure that has implications for the following wheat crop (Naresh et al., 2014). The successful growth of rice on raised beds in northern Australia (Roth et al., 2005) and high yielding irrigated wheat in Mexico under bed were observed. Alteration and development of tillage shows influences on soil fertility and soil environment thereby causing wheat productivity. Although different tillage options have been performed to enhance wheat yield and cultivation in developed countries however, much evidences are not observed in Bangladesh regarding the usage of conventional, permanent and fresh bed system on wheat production. Therefore, wheat yield and yield components 
were assumed to be enhanced in response to these different tillage options.

Crop residues are an important source of soil organic matter vital for the sustainability of agricultural ecosystems. About $25 \%$ of N and P, $50 \%$ of S and $75 \%$ of $\mathrm{K}$ uptake by cereal crops is retained in crop residues, making them valuable nutrient sources (Singh, 2003). However, straw retention is not a common practice in the rice-wheat (RW) systems of Bangladesh, as is also the case elsewhere in South Asia. Wheat and rice straw are usually removed from fields for use as cattle feed and for purposes such as livestock bed ding, thatching material for houses or for fuel, leaving little for incorporation into the soil. The exception is in the northwestern IGP, where most of the rice residues are burnt. Due to the limited number of livestock, farmers throughout the IGP have access to very limited amounts of organic manure. As a result, soil organic matter levels have declined in these cropping systems, and optimization of nutrient uptake and absorption efficiency has become one of the most important goals in crop production strategies. Talukder et al. (2002) reported that $\mathrm{N}$ use efficiency was highest in permanent raised beds, giving higher yields than a conventional system. Limon-Ortega et al. (2000) observed that permanent beds with straw retention had the highest mean wheat grain yields $(5.57 \mathrm{t} / \mathrm{ha}), \mathrm{N}$ use efficiency $(28.2 \mathrm{~kg}$ grain $/ \mathrm{kg}$ of $\mathrm{N}$ supply) and total $\mathrm{N}$ uptake $(133 \mathrm{~kg} / \mathrm{ha})$, with positive implications for soil health. Thus, crop residue management and beds, along with efficient $\mathrm{N}$ fertilization strategies, are likely to be key components of new farming practices that can increase and maintain yields from the intensive RW system in Bangladesh. Straw management with conventional, permanent and fresh bed cropping system might be involved in influencing wheat productivity. Thus the current research was undertaken with the following objectives:

-Performances of bed planting system over conventional and the effect of tillage options on wheat yield and yield components;

-Interaction effect of tillage options and straw management on yield and $\mathrm{N}$-use efficiency; -Interaction effect of tillage options and $\mathrm{N}$ fertilization on wheat productivity.

\section{Materials and Methods}

A cool season wheat (Triticum aestivum)-spring mungbean (Vigna radiata)-monsoon rice cropping pattern was implemented starting with wheat sown in
November 25, 2010 at the Regional Wheat Research Centre, Shyampur (RWRC), Rajshahi, Bangladesh $\left(24^{\circ} 3^{\prime} \mathrm{N}, 88^{\circ} 41 \mathrm{E}, 18 \mathrm{~m}\right.$ above sea level). The site has a subtropical climate and is located in Agro Ecological Zone 11 (High Ganges River Flood Plan) on flood-free high land, with course-textured, highly permeable soil. The area receives $1,257 \mathrm{~mm}$ mean annual rainfall, about $97 \%$ of which occurs from May to September. Total rainfall was highest during the mungbean season and lowest in the wheat season in all years.

The experiment was conducted at Regional Wheat Research Centre, Rajshahi Research Farm to find the effect of fertilizer placement with different tillage options established in the research farm on wheat yield. The three tillage options (permanent raised bed, fresh bed and conventional tillage practice) in a RW cropping system were considered. The experiment was conducted in split plot design with three replications. Wheat variety Prodip was planted at the nationally recommended seeding rate of 100 and $120 \mathrm{~kg} / \mathrm{ha}$ for beds and conventional layout, respectively in early December ( $2^{\text {nd }}$ December, 2010 and 2011) and harvested in late March (28 $8^{\text {th }}$ March, 2011 and 2012). The trial was originally established as a permanent raised bed (PRB) experiment with two straw management practices (main plots- $30 \%$ and $0 \%$ straw retention SR) and three $\mathrm{N}$ levels (subplots $80 \%, 100 \%$, and $120 \%$ of recommended). The area of each subplot was $15 \mathrm{~m}^{2}$ $(5 \mathrm{~m} \times 3 \mathrm{~m})$. The recommended applied NPK rate on wheat crop was $\mathrm{N}(100), \mathrm{P}(30), \mathrm{K}(50), \mathrm{S}(20), \mathrm{kg} / \mathrm{ha}$. Soil analysis has been done by Kjeldahl titration method (Kjeldahl, 1883). Mineral nutrient was available from grain and straw for NPK with Olsen titration method (Olsen et al., 1954). With wheat, two-thirds of the $\mathrm{N}$ was applied before seeding and the remaining one-third at crown root initiation (CRI) (Zadoks growth stage 1.3). Sufficient irrigation water was applied to fill the furrows between the raised beds while the flat plots were flood irrigated. The wheat received three irrigations at CRI (Z1.3), booting (Z4.0-4.9) and grain-filling stages (Z8.0-8.9). Generally, both conventional tillage practice (CTP) and permanent raised bed (PRB) were irrigated on the same days, but less water was needed to fill the furrows with PRB compared to CTP. Manual weed control was done after the first irrigation for wheat.

Statistical analysis of data. MSTAT-C and Microsoft Excel and DMRT were used to measure the variation of mean data of treatments. Treatment means were compared at $\mathrm{P} \leq 0.05$. The data were analysed statistically 
following computer package MSTATC. All the data were statistically analysed following the ANOVA technique and the significance of mean differences was adjusted by Duncan's Multiple Range Test.

\section{Results and Discussion}

Analysis of soil composition. Before experimentation initial soil sample was collected and analysed to know the nutrient status and the results were presented in Table 1 and 2 . The soil was slightly alkaline $(7.8 \mathrm{pH})$ having low organic matter content $(0.94 \%)$ and the total $\mathrm{N}$ content was very low $(0.05 \%)$. Different elements were also analysed from the soil where medium $\mathrm{K}$ level $\left(0.21 \mathrm{M}_{\mathrm{eq}} / 100 \mathrm{~g}\right)$ was observed. In soil P, S and $\mathrm{Zn}$ contents were $10,23.3$ and $0.14 \mu \mathrm{g} / \mathrm{g}$, respectively. In addition, the boron content was found to be very low $(0.27 \mu \mathrm{g} / \mathrm{g})$. The results regarding the soil composition and other parameters reveal that the overall soil fertility status was low.

Effect of tillage options on yield and yield components. As demonstrated in Table 3, grain yield and yield attributes were used to find different tillage options on the development of wheat yield along with other parameters regarding the yield. Although tillage options did not significantly influence on the grain yield and yield components of wheat however, the highest grain yield was found from fresh bed $(4.41 \mathrm{t} / \mathrm{ha})$ which was similar to conventional ( $3.77 \mathrm{t} / \mathrm{ha})$ and permanent bed $(3.98 \mathrm{t} / \mathrm{ha})$. Similar trends were found in yield attributes. Therefore, only tillage options are not associated in

Table 1: Fertility status of initial soil sample of the experimental site at RWRC, BARI, Rajshahi

\begin{tabular}{llll}
\hline \hline Sample & $\mathrm{pH}$ & OM (\%) & Total N (\%) \\
\hline Value & 7.8 & 0.94 & 0.05 \\
Critical level & - & - & 0.12 \\
Interpretation & Slightly & Very & Very \\
& alkaline & low & low \\
\hline \hline
\end{tabular}

Table 2: Elemental analysis of initial soil sample of the experimental site at RWRC, BARI, Rajshahi

\begin{tabular}{llllll}
\hline \hline Sample & $\mathrm{K}$ & $\mathrm{P}$ & $\mathrm{S}$ & $\mathrm{Zn}$ & $\mathrm{B}$ \\
\cline { 4 - 6 } & $\mathrm{M}_{\mathrm{eq}} / 100 \mathrm{~g}$ & \multicolumn{4}{c}{$\mu \mathrm{g} / \mathrm{g}$} \\
Value & 0.21 & 10 & 23.3 & 0.14 & 0.27 \\
Critical level & 0.12 & 10 & 10.0 & 0.60 & 0.20 \\
Interpretation & Medium & Low & Opt. & $\begin{array}{l}\text { Very } \\
\text { low }\end{array}$ & $\begin{array}{l}\text { Very } \\
\text { low }\end{array}$ \\
\hline \hline
\end{tabular}

alterations of inducing the wheat yield and yield attributes and other factors might be involved in this respect. Wheat crop development throughout the season clearly depends on tillage, crop residue management and amount and timing of $\mathrm{N}$ fertilization. Rather than the retention of crop residue as such, the combination of crop residue retention and tillage will induce a change in the nitrogen cycle and as such the timing of $\mathrm{N}$ release (Govaerts et al., 2006). Verhulst et al. (2009) found the effect of different tillage on wheat crop performance. They observed that the conventionally tilled bed-straw incorporated took off fast as compared to the permanent raised bed systems, but plant performance decreased abruptly two weeks after the first auxiliary irrigation. The tillage operations in conventional tilled-straw incorporated might induce a fast $\mathrm{N}$ mineralization at the beginning of the season. Tillage increases aggregate disruption, making organic matter more accessible to soil microorganisms (Six et al., 2002) and increasing mineral $\mathrm{N}$ release from active and physically protected $\mathrm{N}$ pools (Kristensen et al., 2000). Moreover, total dry matter (TDM) was significantly affected by tillage systems for the first year as demonstrated by Wiese (2013). Therefore, it is reasonable that alterations of tillage systems may induce the yield and yield components of wheat.

Interaction effect of tillage options and straw management. Crop growth is the integrated evaluator of the efficiency of the chosen agricultural management system within the boundaries of the agro-ecological environment. Given a cultivar that has been selected for the agro-ecological zone, the crop forms the integrated evaluator of all environmental factors, including the influence of agricultural management and how it determines resource use efficiency. Yield can be measured as an end of season static result of seasonal crop performance, but this does not reflect within season

Table 3. Effect of tillage options on mean yield and yield components of wheat in 2010-11 and 2011-2012

\begin{tabular}{llllll}
\hline \hline $\begin{array}{l}\text { Tillage } \\
\text { options }\end{array}$ & $\begin{array}{l}\text { Spikes/ } \\
\mathrm{m}^{2}\end{array}$ & $\begin{array}{l}\text { Spikelets/ } \\
\text { spike }\end{array}$ & $\begin{array}{l}\text { Grains/ } \\
\text { spike }\end{array}$ & $\begin{array}{l}\text { TGW } \\
(\mathrm{g})\end{array}$ & $\begin{array}{l}\text { Grain yield } \\
(\mathrm{t} / \mathrm{ha})(\mathrm{mean})\end{array}$ \\
\hline Conventional & 343 & 17.2 & 43.2 & 49.6 & 3.77 \\
Permanent bed & 322 & 17.6 & 49.7 & 52.9 & 3.98 \\
Fresh bed & 337 & 17.8 & 50.8 & 54.7 & 4.41 \\
$\mathrm{CV}(\%)$ & 13.14 & 5.34 & 7.59 & 3.65 & 12.44 \\
LSD (0.05) & $\mathrm{NS}$ & $\mathrm{NS}$ & 2.054 & 1.132 & 0.235 \\
\hline \hline TGW=thousand grain weight & & &
\end{tabular}


dynamics of crop performance and its relation with the production environment. In order to understand and evaluate cropping systems and to fine-tune resource management ( $\mathrm{N}$ fertilizer), insight in crop performance over time is crucial. The effect of management factors, such as tillage systems and crop residue management on crop development during the crop cycle has not been studied intensively. As shown in Table 4 and 5, straw management and tillage options influenced significantly among the treatments regarding the yield and yield components of wheat. Maximum grain yield (4.38 and $4.41 \mathrm{t} / \mathrm{ha}$ ) was found from $30 \%$ straw with fresh bed systems in both years (2011-12) and minimum (3.87 and $3.82 \mathrm{t} / \mathrm{ha}$ ) was obtained from $0 \%$ straw retention with conventional method (Table 5). Maximum grains/spike (52.4) was obtained from $30 \%$ straw retention with PB and minimum (48.2) was found from $0 \%$ straw retention with conventional tillage option (Table 4). The results indicate that $30 \%$ straw management has been profoundly recorded to be involved in enhancing the different yield characteristics

Table 4. Interaction effect of tillage options and straw management on mean grain yield attributes of wheat in 2010-2011 and 2011-2012

\begin{tabular}{lllll}
\hline \hline $\begin{array}{l}\text { Tillage options } \times \\
\text { Straw management }\end{array}$ & $\begin{array}{l}\text { Spikes/ } \\
\mathrm{m}^{2}\end{array}$ & $\begin{array}{l}\text { Spikelets/ } \\
\text { spike }\end{array}$ & $\begin{array}{l}\text { Grains/ } \\
\text { spike }\end{array}$ & $\begin{array}{l}\text { TGW } \\
(\mathrm{g})\end{array}$ \\
\hline Conv $\times 0 \%$ Straw & 311 & 17.2 & 48.2 & 53.5 \\
Conv $\times 30 \%$ Straw & 329 & 18.7 & 51.5 & 54.7 \\
PB $\times 0 \%$ Straw & 317 & 17.7 & 48.4 & 53.4 \\
PB $\times 30 \%$ Straw & 321 & 18.7 & 52.4 & 54.5 \\
FB $\times 0 \%$ Straw & 319 & 17.8 & 49.2 & 52.6 \\
FB $\times 30 \%$ Straw & 325 & 18.4 & 52.3 & 54.2 \\
CV $(\%)$ & 11.34 & 5.34 & 7.59 & 3.65 \\
LSD $(0.05)$ & 13.25 & NS & 0.231 & 1.075 \\
\hline \hline
\end{tabular}

Table 5. Interaction effect of tillage options and straw management on grain yield of wheat in 2010-2011 and 2011-2012

\begin{tabular}{lll}
\hline \hline $\begin{array}{l}\text { Tillage options } \times \\
\text { traw management }\end{array}$ & \multicolumn{2}{c}{ Grain yield $(\mathrm{t} / \mathrm{ha})$} \\
\hline Conv $\times 0 \%$ Straw & 3.87 & $2011-12$ \\
Conv $\times 30 \%$ Straw & 4.04 & 3.82 \\
PB $\times 0 \%$ Straw & 4.24 & 4.25 \\
PB $\times 30 \%$ Straw & 4.31 & 4.04 \\
FB $\times 0 \%$ Straw & 4.21 & 4.27 \\
FB $\times 30 \%$ Straw & 4.38 & 4.24 \\
CV $(\%)$ & 12.44 & 4.41 \\
LSD $(0.05)$ & 0.473 & 5.65 \\
\hline \hline
\end{tabular}

in different tillage options. Mohammed et al. (2007) found that the burning of straw increases nutrient availability on the short term. Rather than the retention of crop residue as such, the combination of crop residue retention and tillage will induce a change in the nitrogen cycle and as such the timing of $\mathrm{N}$ release (Govaerts et al., 2006). Therefore, there is a co-relation between the alterations of different tillage and the crop residue such as straw management.

Interaction effect of tillage options and $\mathbf{N}$ fertilization. Grains/spike and TGW were highly significant by the interaction effect of tillage options and $\mathrm{N}$ levels except spike $/ \mathrm{m}^{2}$ and spikelets/spike (Table 6). Maximum grains/ spike (54.4) was found from fresh bed with $120 \% \mathrm{~N}$ application. Statistically similar spike $/ \mathrm{m}^{2}(54.0)$ and (53.2) were also found from fresh bed with $100 \%$ and $80 \% \mathrm{~N}$ application. Table 7 shows the effect of different tillage options as well as N-levels on grain yield of wheat. Grain yield was highly significant by the interaction effect of these factors. The highest grain yield (4.45 and $4.58 \mathrm{t} / \mathrm{ha}$ ) was obtained from fresh bed system with $120 \%$ nitrogen application both the years. Statistically similar yield (4.62 t/ha), $(4.12 \mathrm{t} / \mathrm{ha})$ were obtained from the interaction effect of permanent bed with $120 \%$ nitrogen application. The lowest yield (3.57 and $3.68 \mathrm{t} / \mathrm{ha}$ ) were also found from conventional planting with $80 \% \mathrm{~N}$ application. It is assumed that management of fertilization and involvement of tillage is a major approach for the improvement of wheat production and growth. Properly applied nitrogen fertilizer has a positive effect on crop yield. The longterm influence of fertilizers on crop production in the northern great plains has been researched in some of

Table 6. Interaction effect of tillage options $\times \mathrm{N}$-levels on mean yield components of wheat during 2010-11 and 2011-2012

\begin{tabular}{lllll}
\hline \hline $\begin{array}{l}\text { Tillage options } \\
\times \mathrm{N} \text { levels }\end{array}$ & $\begin{array}{l}\text { Spikes/ } \\
\mathrm{m}^{2}\end{array}$ & $\begin{array}{l}\text { Spikelets/ } \\
\text { spike }\end{array}$ & $\begin{array}{l}\text { Grains/ } \\
\text { spike }\end{array}$ & $\begin{array}{l}\text { TGW } \\
(\mathrm{g})\end{array}$ \\
\hline Conv $\times 80 \% \mathrm{~N}$ & 315 & 17.2 & 48.6 & 53.2 \\
Conv $\times 100 \% \mathrm{~N}$ & 317 & 17.6 & 49.2 & 53.3 \\
Conv $\times 120 \% \mathrm{~N}$ & 337 & 17.2 & 49.4 & 54.4 \\
$\mathrm{~PB} \times 80 \% \mathrm{~N}$ & 311 & 17.9 & 51.5 & 53.2 \\
$\mathrm{~PB} \times 100 \% \mathrm{~N}$ & 314 & 18.3 & 52.4 & 56.4 \\
$\mathrm{~PB} \times 120 \% \mathrm{~N}$ & 322 & 18.2 & 52.6 & 55.2 \\
$\mathrm{FB} \times 80 \% \mathrm{~N}$ & 318 & 17.8 & 53.2 & 53.6 \\
$\mathrm{FB} \times 100 \% \mathrm{~N}$ & 321 & 18.3 & 54.0 & 55.2 \\
$\mathrm{FB} \times 120 \% \mathrm{~N}$ & 330 & 18.8 & 54.4 & 55.1 \\
$\mathrm{CV}(\%)$ & 13.14 & 5.34 & 7.59 & 3.65 \\
LSD $(0.05)$ & $\mathrm{NS}$ & $\mathrm{NS}$ & 0.231 & 1.023 \\
\hline \hline
\end{tabular}


Table 7. Interaction effect of tillage options $\times$ N-levels on yield of wheat during 2010-11 and 2011-12

\begin{tabular}{lll}
\hline \hline \multirow{2}{*}{$\begin{array}{l}\text { Tillage options } \\
\times \mathrm{N} \text { levels }\end{array}$} & \multicolumn{2}{c}{ Grain yield (t/ha) } \\
\cline { 2 - 3 } $2010-11$ & $2011-12$ \\
\hline Conv $\times 80 \% \mathrm{~N}$ & 3.57 & 3.68 \\
Conv $\times 100 \% \mathrm{~N}$ & 3.82 & 3.95 \\
Conv $\times 120 \% \mathrm{~N}$ & 4.04 & 4.32 \\
$\mathrm{~PB} \times 80 \% \mathrm{~N}$ & 3.84 & 3.97 \\
$\mathrm{~PB} \times 100 \% \mathrm{~N}$ & 4.03 & 4.43 \\
$\mathrm{~PB} \times 120 \% \mathrm{~N}$ & 4.12 & 4.62 \\
$\mathrm{FB} \times 80 \% \mathrm{~N}$ & 3.97 & 3.67 \\
$\mathrm{FB} \times 100 \% \mathrm{~N}$ & 4.18 & 4.40 \\
$\mathrm{FB} \times 120 \% \mathrm{~N}$ & 4.45 & 4.58 \\
$\mathrm{CV}(\%)$ & 12.44 & 9.96 \\
LSD $(0.05)$ & 0.473 & 0.575 \\
\hline \hline
\end{tabular}

the studies (Campbell et al., 2005). Most studies have demonstrated the need for and benefit of, applying adequate fertilizers to achieve optimum economic returns (Zentner et al., 2007; Campbell et al., 1990).

\section{Conclusion}

In the ongoing study, fresh bed with $120 \% \mathrm{~N}$ application was found maximum grain yield but statistically similar yields were also found from fresh bed and permanent bed with 100 and $120 \% \mathrm{~N}$ application. It was also similar with conventional tillage practice (CTP) with $120 \%$ nitrogen application. The higher grain yield, total grain weight and other yield components were found to be higher for fresh bed rather than conventional or permanent cropping systems. The strategy applied in enhancing the wheat yield may give an insight in development of wheat cultivation in Bangladesh. Consequently, there is need to conduct long term experiments so as to make appropriate measurements and assessments of the influence of such recommended management practices on sustainable production.

\section{References}

Connor, D.J., Timsina, J., Humphreys, E. 2003. Prospects for permanent beds for the rice-wheat system. In: Improving the Productivity and Sustainability of Rice-Wheat Systems: Issues and Impacts, J. K. Ladha et al. (eds.), pp. 65, 197-210. ASA Special Publication.

Campbell, C.A., Zentner, R.P., Selles, F., Jefferson, P.G., McConkey, B.G., Lemke, R., Blomert, B.J. 2005. Longterm effect of cropping systems and nitrogen and phosphorus fertilizer on production and nitrogen economy of grain crops in a Brown Chernozem. Canadian Journal of Plant Science, 85: $81-93$.

Campbell, C.A., Zentner, R.P., Janzen, H.H., Bowren, K.W. 1990. Crop rotation studies on the Canadian Prairies, 133 pp., Canadian Govt. Pub 1. Centre, Supply \& Services, Hull, QC. Publ. 1841/E.

Govaerts, B., Sayre, K.D., Ceballos-Ramirez, J.M., Luna-Guido, M.L., Limon-Ortega, A., Deckers, J., Dendooven, L. 2006. Conventionally tilled and permanent raised beds with different crop residue management: Effects on soil $\mathrm{C}$ and $\mathrm{N}$ dynamics. Plant and Soil, 280: 143-155.

Feng-Zheng, W., Hui- Jin-Cai, L., Cheng- Yu, W., HuiJuan, Q. U., Xue-Shan, S. 2008. Effects of nitrogenous fertilizer application model on culm lodging resistance in winter wheat. Acta Agronomic Sinica, 34: 1080-1085.

Kjeldahl, J. 1883. New method for the determination of nitrogen in organic substances. Zeitschrift für Analytische Chemie, 22: 366-383.

Kristensen, H.L., McCarty, G.W., Meisinger, J.J. 2000. Effects of soil structure disturbance on mineralization of organic soil nitrogen. Soil Science Society of America Journal, 64: 371-378.

Limon-Ortega, A., Sayre, K.D., Francis, C.A. 2000. Wheat nitrogen use efficiency in a bed planting system in northwest Mexico. Agronomy Journal, 92: 303-308.

Mohamed, A., Hardtle, W., Jirjahn, B., Niemeyer, T., Oheimb, G.V. 2007. Effects of prescribed burning on plant available nutrients in dry heathland ecosystems. Plant Ecology, 189: 279-289.

Naresh, R.K., Tomar, S.S., Kumar, D., Samsher, Purushottam, Singh, S.P., Dwivedi, A., Kumar, V. 2014. Experiences with rice grown on permanent raised beds: effect of crop establishment techniques on water use, productivity, profitability and soil physical properties. Rice Science, 21: 170-180.

Olsen, S.R., Cole, C.V., Watanabe, F.S., Dean, L.A. 1954. Estimation of available phosphorus in soils by extraction with sodium bicarbonate, pp. 1-18, USDA Circular No. 939, United States Department of Agriculture, Washington, DC., USA.

Roth, C.H., Fischer, R.A., Meisner, C.A. (eds), 2005. Evaluation and performance of permanent raised bed cropping systems in Asia, Australia and Mexico. Proceedings of a Workshop held in Griffith, Australia, 1-3 March 2005. ACIAR Proceedings No. 121, pp. 1-200. 
Sah, G., Shah, S.C., Sah, S.K., Thapa, R.B., McDonald, A., Sidhu, H.S., Gupta, R.K., Sherchan, D.P., Tripathi, B.P., Davare, M., Yadav, R. 2014. Tillage, crop residue, and nitrogen level effects on soil properties and crop yields under rice-wheat system in the Terai region of Nepal. Global Journal of Biology, Agriculture \& Health Sciences, 3: 139147.

Singh, Y. 2003. Crop residue management in rice-wheat system. In: Addressing Resource Conservation Issues in Rice-Wheat Systems of South Asia: A Resource Book, vol. 153: pp 153-156. Rice-Wheat Consortium for the Indo-Gangetic Plains RWC CIMMYT, New Delhi, India.

Six, J., Conant, R.T., Paul, E.A., Paustian, K. 2002. Stabilization mechanisms of soil organic matter: Implications for C-saturation of soils. Plant and Soil, 241: 155-176.

Talukder, A.S.M.H.M., Sufian, M.A., Meisner, C.A., Duxbury, J.M., Lauren, J.G., Hossain, A.B.S. 2002. Rice, wheat and mungbean yields in response to $\mathrm{N}$ levels and management under a bed planting system. In: Proceedings of the $17^{\text {th }}$ World Congress of Soil Science Symposium, no. 11, 351 pp., vol. 1, Bangkok, Thailand.
Timsina, J., Connor D.J. 2001. Productivity and management of rice-wheat cropping systems: issues and challenges. Field Crops Research, 69: 93-132.

Verhulst, N., Govaerts, B., Kienle, F., Tijerina-Chavez, L., Deckers, J., Raes, D., Sayre, K.D. 2009. The effect of tillage, crop residue management and nitrogen fertilization on wheat crop performance in an irrigated bed planting system in Northwestern Mexico, In: Proceeding of the International Soil Tillage Research Organization, pp.1-11, ISTRO $18^{\text {th }}$ Triennial Conference Proceedings, June 1519, 2009, Izmir-Turkey,

Wiese, J.D. 2013. The effect of crop rotation and tillage practice on soil moisture, nitrogen mineralisation, growth, development, yield and quality of wheat produced in the Swartland area of South Africa, pp. 1-94. M.Sc Thesis, Faculty of Agriculture at Stellenbosch University, South Africa.

Zentner, R.P., Campbell, C.A., Selles, F., Lemke, R., McConkey, B.G., Fernandez, M.R., Hamel, C., Gan, Y.T. 2007. Economics of spring wheat production systems using conventional tillage manage in the brown soil zone- revisited. Canadian Journal of Plant Science, 87: 27-40. 